\title{
Restoring Crested Wheatgrass Stands to Big Sagebrush for Improved Sage-Grouse Habitat: A Literature Review
}

\author{
Krystle A. Wengreen \\ Department of Animal and Range Sciences, Montana State University \\ PO Box 172900, 103 Animal Bioscience Building, Bozeman, MT 59717-2900, USA
}

Tel: 1-208-845-2001Ｅ-mail: kwengreen@blm.gov

\begin{abstract}
Michael Frisina
Department of Animal and Range Sciences, Montana State University

PO Box 172900, 103 Animal Bioscience Building, Bozeman, MT 59717-2900, USA
\end{abstract}

Tel: 1-406-994-7164Ｅ-mail: mfrisina@ bresnan.net

Julie L. Hager

Department of Animal and Range Sciences, Montana State University

PO Box 172900, 103 Animal Bioscience Building, Bozeman, MT 59717-2900, USA

Tel: 1-406-994-7953Ｅ-mail: jhager@montana.edu

Bok F. Sowell (Corresponding author)

Department of Animal and Range Sciences, Montana State University

PO Box 172900, 103 Animal Bioscience Building, Bozeman, MT 59717-2900, USA

Tel: 1-406-994-5558_E-mail: bok@montana.edu

Received: June 25, 2016 Accepted: July 21, 2016

doi:10.5296/emsd.v5i2.9895 URL: http://dx.doi.org/10.5296/emsd.v5i2.9895

\section{Abstract}

Greater sage-grouse (Centrocercus urophasianus) is a high priority species for federal and 
state land management agencies in the Western United States. Sage-grouse are sagebrush (Artemisia spp.) obligates requiring sagebrush for their survival throughout the year. Sagebrush has been removed and replaced with crested wheatgrass (Agropyron cristatum \& A. desertorum) throughout the West. The objectives of this paper were to review the literature (100 papers), as well as consult experts, to determine which methods are most likely to eliminate crested wheatgrass and establish sagebrush. No technique eliminates crested wheatgrass in a single application but research suggests it should not comprise more than $14 \%$ cover for successful reseeding of other species. Grazing and fire have no long-term impacts on crested wheatgrass. Mechanical treatments, such as plowing, disking, and cultivating reduce and eradicate crested wheatgrass, but a flush of invasive annual grasses following mechanical disturbance can make establishment of seeded species difficult. If invasive plant establishment is a problem with mechanical treatments, crested wheatgrass stands should be treated with glyphosate in early spring for two consecutive years at a rate of $1.1 \mathrm{~kg} / \mathrm{ha}$ of active ingredient. Then, sagebrush should be seeded in the late fall using a compact row seeder or Brillion cultipacker at a rate of $0.22 \mathrm{~kg} / \mathrm{ha}$ pure live seed.

Keywords: Agropyron cristatum, Agropyron desertorum, Artemisia, Centrocercus urophasianus

\section{Introduction}

Greater sage-grouse (Centrocercus urophasianus) is a high priority species for United States of America federal and state land management agencies. In 2005 there were three petitions to list greater sage-grouse as threatened or endangered under the Endangered Species Act of 1973 (United States Fish and Wildlife Service 2005). The United States Fish and Wildlife Service (USF\&WS) decided to not list this species in 2015, but will review the decision in 5 years. Breeding populations of sage-grouse have declined by 17 to 47 percent throughout much of their range during the last 70 years due to decreases in the quality and quantity of sagebrush habitats (Connelly, Schroeder, Sands and Braun 2000). Sage-grouse are sagebrush (Artemisia spp.) obligates requiring sagebrush for their survival throughout the year (Connelly, Schroeder, Sands and Braun 2000). Sagebrush has been removed and replaced with crested wheatgrass (Agropyron cristatum (L.) Gaertn. \& A. desertorum (Fisch. ex Link) J.A. Schultes) throughout the West (Lorenz 1986). Crested wheatgrass stands form monocultures, with low sagebrush cover and understory plant species diversity (Heidinga \& Wilson 2002, Henderson \& Naeth 2005). The Bureau of Land Management (BLM) in Montana has committed funds to restore crested wheatgrass to sagebrush to provide more suitable sage-grouse habitat (J. Parks, personal communication, Sept 2007).

Land managers have been engaged in a number of practices to reduce or eliminate crested wheatgrass and establish sagebrush in the western United States. Unfortunately, there has not been a synthesis of this information available to other land managers. Scientific studies usually offer the most rigorous testing of our theories on how to convert crested wheatgrass to sagebrush, but there are many people that have obtained a wealth of knowledge which are not contained in the scientific literature. Land managers are also interested in the costs of control, establishment and seed, so we have included these items for consideration. 


\section{Mll Macrothink}

Environmental Management and Sustainable Development

ISSN 2164-7682

2016, Vol. 5, No. 2

The objectives of this paper are to review the literature, as well as consult experts, to determine which methods are most likely to be successful to eliminate crested wheatgrass and establish sagebrush to improve sage-grouse habitat. Crested wheatgrass elimination techniques reviewed include grazing, burning, chemical and mechanical treatments. Sagebrush establishment techniques reviewed include drilling and broadcasting seed.

\section{Methods}

This study was based on a review of 100 papers. Eighteen papers were government reports, seven were theses, seven were published in symposium proceedings, and the 68 remaining were peer-reviewed, scientific studies. Twenty-five studies dealt with sage-grouse habitat requirements, and the remaining 75 dealt specifically with modifying crested wheatgrass stands or establishing sagebrush. Four of the 75 crested wheatgrass studies were observational, but relied on long-term records to reach their conclusions. Results from the literature presented in this review were included if there was a significant $P$-value $(0.05)$. Differences of opinion between papers were resolved by giving preference to long-term replicated studies with strong experimental designs. All 100 studies were reviewed to reach management recommendations.

In order to ensure that our conclusions and management recommendations were reasonable, we consulted seven experts experienced with crested wheatgrass and sagebrush establishment. Experts were chosen based on experience or volume of published reports (Table 1).

Table 1. Experts consulted on crested wheatgrass control and sagebrush establishment.

\begin{tabular}{|l|l|}
\hline Consultant & Organization \\
\hline Dr. Mike Pellant & Idaho State Bureau of Land Management (BLM) Great Basin Initiative Coordinator \\
\hline Dr. Nancy Shaw & United States Forest Service (USFS) Research Botanist \\
\hline Dr. Bruce Roundy & Brigham Young University Plant and Wildlife Sciences Professor \\
\hline Dr. Jane Mangold & Department of Land Resources and Environmental Sciences, Montana State University \\
\hline Steve Monsen & USFS Botanist (retired) \\
\hline Kyle Wendtland & Cloud Peak Energy, Antelope Mine Powder River Basin, Wyoming \\
\hline Stuart Wengreen & Simplot Grower Solutions Certified Crop Advisor \\
\hline
\end{tabular}

\section{Literature Review}

\subsection{Sage-grouse Habitat Requirements}

Sage-grouse are a sagebrush obligate species and require large tracts of relatively continuous sagebrush cover (Connelly, Schroeder, Sands \& Braun 2000). Sage-grouse require sagebrush throughout the entire year. Sagebrush comprised 62 percent of the year-long diet of adult sage grouse and essentially 100 percent of their winter diet in Montana (Wallestad, Peterson, \& Eng 1975). Sage-grouse require a variety of shrubs in different quantities for wintering, breeding, nesting, and brood-rearing (Connelly, Schroeder, Sands \& Braun 2000, Crawford et al. 2004).

Sage-grouse are completely dependent on sagebrush communities throughout the winter (Wambolt et al. 2002). During the winter, sage-grouse commonly use medium to tall 
sagebrush communities on south and west facing slopes (Connelly, Schroeder, Sands \& Braun 2000), as well as sagebrush habitats with 12 (Woodward 2006) to 20 percent canopy cover in Montana (Wallestad et al. 1975). Sage-grouse used areas with $1.2 \mathrm{shrubs} / \mathrm{m} 2$ in central Montana (Woodward 2006). Sage-grouse feed almost exclusively on sagebrush throughout the winter, with big sagebrush (A. tridentata Nutt.) dominating their diet (Wallestad et al. 1975). Other sagebrush species such as low sagebrush (A. arbuscula Nutt.), black sagebrush (A.nova A. Nels.), fringed sagebrush (A. frigida Willd.), and silver sagebrush (A. cana Pursh) are consumed depending on availability (Wambolt et al. 2002).

Lekking or breeding habitat is typically located in open areas surrounded by sagebrush, which may include ridgetops, swales, dry lakebeds, burned areas, or plowed fields (Connelly, Arthur \& Markham 1981, Gates 1985). Sage-grouse males tend to form leks in areas that are within or adjacent to potential nesting habitat (Connelly, Schroeder, Sands and Braun 2000). Sagebrush, herbaceous plant cover, and insects are major components of the lek habitat (Connelly, Schroeder, Sands \& Braun 2000).

During the pre-laying period, 50 to 80 percent of the hen's diet is sagebrush (Barnett and Crawford 1994, Crawford et al. 2004). Pre-laying hens need a diversity of forbs high in calcium, phosphorus, and protein (Barnett \& Crawford 1994). The quality of the pre-laying areas may impact nest initiation rate, clutch size, and future reproductive successes (Barnett $\&$ Crawford 1994). During the pre-laying period habitat use centers around low sagebrush and Wyoming big sagebrush (A. tridentata ssp. wyomingensis Rydb.; (Crawford et al. 2004).

Sage-grouse require sagebrush stands with 15 to 38 percent sagebrush cover for nesting and almost always nest under sagebrush (Connelly, Schroeder, Sands \& Braun 2000, Lane 2005, Sika 2006, Woodward 2006). In Montana 91 percent of sage-grouse nested under sagebrush, with less than two percent nesting under crested wheatgrass (Lane 2005). In another study in Montana, 91 percent were located under sagebrush and six percent were located in either seeded grasslands (includes crested wheatgrass) or alfalfa fields (Sika 2006). Nest success is higher (53 percent) when sage-grouse are able to use sagebrush, compared with non-sagebrush nests (22 percent) (Connelly, Wakkinen, Apa \& Reese 1991). Sage-grouse nest selection is related to sagebrush height and cover (Crawford et al. 2004, Klebenow 1969). Sage-grouse nest sites commonly occur in sagebrush stands with 15 to 38 percent sagebrush cover, 3 to 30 percent herbaceous plant cover and 14 to $34 \mathrm{~cm}$ grass heights (Connelly, Schroeder, Sands \& Braun 2000). The average height of sagebrush associated with nests was between 29 to $80 \mathrm{~cm}$, with nests commonly under the tallest sagebrush within a stand ( Connelly, Schroeder, Sands \& Braun 2000, Wallestad \& Pyrah 1974). In central Montana, sage-grouse nest habitats had 15 percent shrub cover with an average height of $28 \mathrm{~cm}$ and a density of 1.4 shrubs/m2 (Woodward 2006). Another study in Montana found that nesting habitat had shrub cover of 9 to 12 percent (Moynahan 2004). Sage-grouse depend on grasses and forbs in the understory, which may provide scent, visual, and physical barriers to potential predators (Delong, Crawford \& Delong 1995).

Brood-rearing areas are commonly in upland sagebrush habitat (Connelly, Schroeder, Sands $\&$ Braun 2000). Most are relatively open stands of sagebrush with 14 percent canopy cover 
and $\geq 15$ percent herbaceous plant cover (Martin 1970, Sveum, Crawford \& Edge 1998, Wallestad 1971). Most (90 percent) brood sites are located in Wyoming big sagebrush while less than four percent are found in crested wheatgrass (Lane 2005). In central Montana, brood sites had 14 percent shrub cover with an average shrub height of $28 \mathrm{~cm}$ and a density of 1.4 shrubs/m2 (Woodward 2006). Most brood areas are characterized by high plant species richness with abundant forbs and insects (Drut, Crawford \& Gregg 1994 , Dunn \& Braun 1986, Klott \& Lindzey 1990). Diets of sage-grouse chicks included 34 genera of forbs and 41 families of invertebrates in Oregon (Drut, Pyle \& Crawford 1994). Forbs and insects comprise the majority of chick diets until they are 12 weeks old, when sagebrush becomes a major component (Klebenow \& Gray 1968). As the growing season progresses, more mesic habitats, such as riparian areas, are used as forbs desiccate (Crawford et al. 2004, Wallestad 1971).

\subsection{Crested Wheatgrass History}

Between 13 to 17 million ha of crested wheatgrass have been planted in North America (Bakker \& Wilson 2004) since it was introduced from Russia in 1897 (Dillman 1946, Lorenz 1986). In the early 1900s, crested wheatgrass, a drought and cold resistant plant, quickly became the most commonly used introduced perennial grass species for revegetation in the northern Great Plains and much of the West (Laycock 1981, Rogler \& Lorenz 1983, Sharp 1986). Crested wheatgrass was used to control erosion, increase livestock forage, control weeds, and reduce wildfires (Lorenz 1986, Smoliak \& Dormaar 1985, Young \& Evans 1986). The first large scale plantings of crested wheatgrass was prompted by large sheep losses to halogeton (Halogeton glomeratus (Bieb.) C.A. Mey.) poisoning (Mathews 1986). Land managers needed a perennial plant that would suppress and crowd out halogeton (Mathews 1986).

Crested wheatgrass has been planted over a large portion of the historic and current range of sage-grouse (Connelly, Schroeder, Sands \& Braun 2000, Rogler \& Lorenz 1983, Schroeder et al. 2004). Crested wheatgrass forms large homogenous stands, lacking the sagebrush and plant species diversity required by sage-grouse (Crawford et al. 2004, Heidinga \& Wilson 2002). Sagebrush cover is lower in crested wheatgrass stands when compared to native sagebrush grasslands (McAdoo, Longland \& Evans 1989). Large crested wheatgrass stands become monocultures and displace native plant species, such as sagebrush, for 40 to 50 years (Hull \& Klomp 1966, Looman \& Heinrich 1973, Marlette \& Anderson 1986). Where sagebrush is completely removed sage-grouse will cease to nest (Klebenow 1969). Dense crested wheatgrass stands reduce feed and structure for sage-grouse adults and chicks (Pellant \& Lysne 2005) by excluding native grasses, shrubs, and forbs. Lower plant species diversity in crested wheatgrass result in reduced populations of invertebrates necessary for survival and growth of sage-grouse chicks (DeLuca \& Lesica 1996). Increasing sagebrush within crested wheatgrass stands would improve habitat for sage-grouse throughout the year.

\subsection{Crested Wheatgrass Conversion}

Because crested wheatgrass competes for light, nutrients and water, it must be reduced or eliminated to facilitate the establishment of sagebrush (Pellant \& Lysne 2005). The greatest 
obstacle to seedling establishment in any habitat is the vegetation currently established in that habitat (Grubb 1977). Control of herbaceous vegetation is necessary for successful sagebrush establishment, because grasses out compete young shrubs (Kiger, Berg, Herron, Phillips, \& Atkinson 1987). Crested wheatgrass is a prolific seed producer and has a large, viable seed bank in the soil, which may affect the success of suppression or eradication strategies (Marlette \& Anderson 1986, Pellant \& Lysne 2005). We reviewed the use of grazing, fire, mechanical and/or chemical treatments to determine the best method to reduce crested wheatgrass cover sufficient for sagebrush establishment.

\subsubsection{Grazing}

We have summarized the responses of crested wheatgrass to grazing in Table 2. Crested wheatgrass persisted after 20 years of annual heavy spring grazing (Hubbard 1949), even though grazing occurred when it should be most deleterious (Olson \& Richards 1988). Mowing crested wheatgrass in the fall did not reduce the basal area compared to the control the following spring (Lodge 1960). When grazing pressure was removed, stands recovered quickly, doubling yields two seasons after grazing ceased (Hull \& Klomp 1966).

Clipping may not have an impact on crested wheatgrass cover, but seed production can be reduced to zero (Cook, Stoddart \& Kinsinger 1958, Hansen and Wilson 2006). Growth may be reduced under cumulative, repetitive defoliation due to reduced root growth and thus reduce its ability to take up nutrients (Hansen \& Wilson 2006). Even though seed production was reduced, it has been shown that overall crested wheatgrass cover is unaffected by long-term grazing (Table 2).

Table 2. Summary of Studies of Grazing to Eliminate Crested Wheatgrass

\begin{tabular}{|l|l|l|}
\hline \multirow{2}{*}{ Authors } & \multicolumn{2}{|l|}{ Eliminates Crested Wheatgrass } \\
\cline { 2 - 3 } & Yes & No \\
\hline Caldwell Richards, Johnson, Nowak \& Dzurec 1981 & & $\mathrm{X}$ \\
\hline Cook, Stoddart \& Kinsinger 1958 & & $\mathrm{X}$ \\
\hline Hull 1974 & & $\mathrm{X}$ \\
\hline Hull \& Klomp 1966 & & $\mathrm{X}$ \\
\hline Laycock \& Conrad 1981 & & $\mathrm{X}$ \\
\hline Frischknecht \& Harris 1968 & $\mathrm{X}$ \\
\hline Hubbert 1949 & $\mathrm{X}$ \\
\hline
\end{tabular}

\subsubsection{Burning}

Burning crested wheatgrass has no long-term impacts on biomass production (Lodge 1960, Romo, Grilz \& Delanoy 1994). Fall burning to rejuvenate pastures reduced the yield of crested wheatgrass, but in the following years, production equaled or exceeded controls (Lodge 1960). Spring burning reduced crested wheatgrass production for two years, but returned to control levels after two years. The vegetative cover of crested wheatgrass was unchanged two seasons following spring or fall burns in two separate studies almost 35 years apart in Saskatchewan (Lodge 1960, Romo, Grilz \& Delanoy 1994). The cost of prescribed burning varies between approximately $\$ 10.00$ and $\$ 80.00 /$ ha depending on the size of the 


\section{MInstitute Machink $_{\text {Int }}$}

burn (Gee \& Biermacher 2007). Because burning does not reduce crested wheatgrass cover, it is not a useful pretreatment for sagebrush establishment.

\subsubsection{Mechanical Treatments}

Mechanical treatments are effective in removing or reducing vigor in crested wheatgrass plants (Table 3). Common treatments include disking, rototilling, cultivating, and harrowing and most of the studies have been summarized in Table 3 .

The effectiveness of mechanical treatments varies greatly and problems with increased soil erosion and weed entry may impact their usefulness for establishing native plant species (Pellant \& Lysne 2005). The drawbacks associated with mechanical treatments include the increased susceptibility to wind and water erosion, loss of the soil structure, disruption of soil moisture and nutrient cycling, and the increased risk for establishment of undesirable species (Bakker 1996). Facilitation of topsoil erosion is of particular concern when treatments result in complete removal of crested wheatgrass (Lorenz \& Rogler 1962). Tillage also damages desirable, native plants that may be present within crested wheatgrass stands.

A flush of invasive annual grasses following mechanical disturbance can make establishment of seeded species difficult (King, Waller, Moser \& Stubbendieck 1989). In the Great Basin, cheatgrass (Bromus tectorum L.) invades sites that have been mechanically disturbed making establishment of sagebrush difficult (M. Pellant, personal communication, October 2007). Cheatgrass is an introduced annual grass that dominates 1.3 million ha of public lands in the Great Basin and another 30.8 million ha are classified as either infested or susceptible to cheatgrass invasion (Pellant \& Hall 1994). Annual weedy species such as cheatgrass reduce the success of sagebrush establishment (Cook 1974). In Utah, cheatgrass cover was not affected by tilling, harrowing, or herbicide applications (Cox \& Anderson 2004). It is crucial to know if invasion by cheatgrass or other invasive weeds is a risk before mechanical treatments are performed.

Prices of various mechanical treatments range from $\$ 59 /$ ha to plow, $\$ 39 /$ ha to disk and $\$ 35 /$ ha to harrow, which are based on custom farming rates ( $\mathrm{S}$. Wengreen, personal communication, October 2007). Mechanical treatments are effective in reducing crested wheatgrass cover enough to establish sagebrush, but may not be worth the risk of invasion by weedy annual grasses like cheatgrass.

Table 3. Summary of Studies Using Mechanical Methods to Eliminate Crested Wheatgrass

\begin{tabular}{|c|c|c|c|c|}
\hline \multirow[b]{2}{*}{ Authors } & \multirow[b]{2}{*}{ Treatment } & \multicolumn{3}{|c|}{ Eliminates Crested Wheatgrass } \\
\hline & & $\%$ Reduction & Yes & No \\
\hline Pellant \& Lynse 2005 & & & $\mathrm{X}$ & \\
\hline Lodge 1960 & Double disking & $75 \%$ & $\mathrm{X}$ & \\
\hline Bakker, Christian, Wilson \& Waddington 1997 & Rototilling & & $\mathrm{X}$ & \\
\hline Lorenz \& Rogler 1962 & Plowing & & $\mathrm{X}$ & \\
\hline Cox \& Anderson 2004 & Cultivator & $90 \%$ & $\mathrm{X}$ & \\
\hline Cox \& Anderson 2004 & Harrow & $58 \%$ & $\mathrm{X}$ & \\
\hline
\end{tabular}




\subsubsection{Chemical Treatments}

The use of appropriate herbicides can help control crested wheatgrass and thus improve the opportunity for establishment of seeded species (Whisenant 1999). Application of glyphosate ( $N$-[phosphonomethyl]glycine), a generalist herbicide, has been shown to be effective in reducing vigor or causing mortality of crested wheatgrass (Table 4). Glyphosate applications reduce growth of treated crested wheatgrass plants for about eight weeks, providing a period of reduced competition (Gobin 1994). Herbicide application at the correct phenological stage (8 to $15 \mathrm{~cm}$ height) is crucial for determining treatment effectiveness. Applications in the early spring when crested wheatgrass is beginning growth and before desired native species initiate growth, appears to be the most effective (Ambrose \& Wilson 2003, Bakker, Christian, Wilson \& Waddington 1997, Bakker et al. 2003, Peat \& Bowes 1995, Romo, Grilz \& Delanoy 1994). Glyphosate applications should not be relied upon to completely eliminate crested wheatgrass (Table 4). Eleven studies are summarized in Table 4.

Cox and Anderson (2004) found that two herbicide applications reduced crested wheatgrass cover by 2 to 77 percent in Utah. Sagebrush and rabbitbrush (Ericameria nauseosa (Pallas ex Pursh) Nesom \& Baird) were then seeded into treated plots using three methods (Cox and Anderson 2004). Crested wheatgrass cover was reduced to 4 percent the first year and 14 percent the second year. There was little to no establishment of sagebrush or rabbitbrush when crested wheatgrass cover was above 14 percent. Thus 14 percent provides an approximate threshold for the maximum crested wheatgrass cover allowed for establishment of shrubs in crested wheatgrass stands (Cox \& Anderson 2004). Sagebrush and rabbitbrush emergence was 1.5 plants $/ \mathrm{m} 2$ in drilled plots and 0.6 plants $/ \mathrm{m} 2$ in broadcast and covered plots when glyphosate was applied in early spring for two consecutive years prior to planting (Cox \& Anderson 2004). Tilling the seedbed prior to drilling resulted in 2.1 plants $/ \mathrm{m} 2$, while harrowing prior to drilling resulted in 1.1 plant $/ \mathrm{m} 2$. Although the tillage/drill treatment combination resulted in the highest shrub establishment, even the lower density of 0.6 plants/m2 would be an acceptable density if these shrubs fully established. Plots were reexamined in the second growing season to assess establishment. Tilled and drilled plots resulted in 3.9 shrubs $/ \mathrm{m} 2$ and harrow and drill plots resulted in 1.8 shrubs $/ \mathrm{m} 2$. Herbicide and drilled plots resulted in 2.1 shrubs/m2 and broadcast and cover plots yielded 0.9 shrubs $/ \mathrm{m} 2$. Establishment data is consistent with emergence data, where tilled plots had the highest rates of shrub establishment. The second year of the study had little emergence or establishment of any seeded plant species due to a lack of precipitation. During the first year there was above average precipitation in February and March which facilitated the establishment of seeded species (Cox \& Anderson 2004).

Because drought years have a large impact on the establishment, seed may have to be applied a few times if there are years of below average precipitation (Cox \& Anderson 2004, Johnson 2004). Nafus, Svejcar and Davies (2016) found that herbicide treated crested wheatgrass seeding sites had fewer shrubs than sites that were burned or scarified. The price of spraying herbicide at a rate of $1.1 \mathrm{~kg} / \mathrm{ha}$ of active ingredient (Bakker, Christian, Wilson \& Waddington 1997, Bakker et al. 2003, Hansen \& Wilson 2006, Wilson \& Partel 2003) is approximately $\$ 34 /$ ha (S. Wengreen, personal communication, October 2007). Herbicide applications do not 
cause the large scale soil disturbances that mechanical treatments do, making them a better option for avoiding weed invasion (M. Pellant, personal communication, October 2007).

Table 4. Summary of Studies Using Chemical Treatments to Control Crested Wheatgrass

\begin{tabular}{|l|c|c|c|c|c|}
\hline & & \multicolumn{2}{|c|}{$\begin{array}{c}\text { Reduces } \\
\text { growth }\end{array}$} & \multicolumn{2}{c|}{$\begin{array}{c}\text { Eliminates Crested } \\
\text { Wheatgrass }\end{array}$} \\
\hline Authors & Herbicide & Yes & No & Yes & No \\
\hline Bakker et al. 1994 & Glyphosate & & & & \\
\hline Wilson \& Gerry 1995 & Glyphosate & X & & X & \\
\hline Wilson \& Partel 2003 & Glyphosate & & & & X \\
\hline Gobin 1994 & Glyphosate & & & & \\
\hline Ambrose \& Wilson 2003 & Glyphosate & X & & & \\
\hline Bakker, Christian, Wilson \& Waddington 1997 & Glyphosate & X & & & \\
\hline Bakker et al. 2003 & Glyphosate & X & & & X \\
\hline Peat \& Bowes 1995 & Glyphosate & X & & & X \\
\hline Romo, Grilz \& Delanoy 1994 & Glyphosate & X & & & X \\
\hline Cox \& Anderson 2004 & Glyphosate & X & & & \\
\hline Hansen \& Wilson 2006 & Glyphosate & X & & & \\
\hline
\end{tabular}

\subsection{Sagebrush Establishment}

Sagebrush can be seeded once crested wheatgrass cover has been reduced to below 14 percent (Cox \& Anderson 2004). Desired plant species, such as sagebrush or other native plants, must be planted as seeds or as bare root stock. Successful sagebrush seedings should result in a shrub density of at least 1.2 to $1.4 \mathrm{shrubs} / \mathrm{m} 2$. This is an average based on the areas occupied by sage-grouse during nesting, brood-rearing, and wintering in central Montana (Woodward 2006). Typically, long term survival rates of seeded sagebrush are less than 60 percent (Schuman \& Belden 2002 , Kiger, Berg, Herron, Phillips \& Atkinson 1987), so it may not be possible to fully evaluate seeding success until 8 or more years after initial seeding (Schuman, Vicklund \& Belden 2005)

\subsubsection{Seedbed Ecology and Preparation of Shrubs}

Precipitation can negatively or positively influence species composition, productivity, survival, and establishment (Bleak, Frishknect, Plummer \& Eckert 1965, Lauenroth, Sala, Coffin \& Kirchner 1994, Sala, Parton, Joyce \& Lauenroth 1988, Weaver 1950) . Climatic conditions strongly influence establishment even with proper site preparation and seeding methods (Call \& Roundy 1991, Cox \& Anderson 2004, Johnson 2004). Establishment of shrubs such as sagebrush can be difficult. Many failures are due to inadequate soil moisture at the time of germination and during the initial growth period (Holmgren 1956). Drought is the main cause of sagebrush seedling mortality (Meyer 1992). Late fall or early winter are the best times to plant sagebrush, as this is when sagebrush seed disperses naturally and soil surfaces are likely to be moist (Shaw, Debolt \& Rosentreter 2005). Seedings have been most successful when done in the late fall or early winter just prior to snowfall (Lambert 2005, Monsen 2000, Stevens \& Monsen 2004). Sagebrush seeding in the spring is not recommended (Meyer 1992). Sagebrush seed requires 20 to 30 days of moisture to germinate; surface moisture within the top 0.2 to $0.5 \mathrm{~cm}$ of soil is critical (S.B. Monsen, personal communication, October 2007). 
Exploiting weather conditions can help improve sagebrush seeding success (S.B Monsen, personal communication, October 2007; M. Pellant, personal communication, October 2007; K. Wendtland, personal communication, October 2007). In the Powder River Basin of Wyoming, seeding sagebrush prior to storms in the late fall provides the best opportunity for establishment (K. Wendtland, personal communication, October 2007). The amount and timing of winter snowfall has a large impact on sagebrush seedling emergence. A single late-winter snowfall made the difference between zero percent emergence at one site and 80 percent emergence at a similar site in Wyoming (Monsen \& Meyer 1990). Emergence is rarely achieved unless winter snow is present (Meyer 1992).

Big sagebrush should be planted on a firm seedbed with only a light covering of soil. Rough seedbeds may bury the seed too deeply (Shaw, Debolt \& Rosentreter 2005). Providing a very firm seedbed is crucial for sagebrush establishment, so it may be necessary to use a cultipacker or some machinery to pack down the soil (K. Wendtland, personal communication, October 2007). It is crucial that seed not be buried too deeply (Monsen 2000, Lambert 2005). Site preparation or planting methods that create a loose, sloughing seedbed should be avoided (Meyer 1992).

\subsubsection{Sagebrush Seeding Rates}

Suggested seeding rates for basin big sagebrush (A. tridentata Nutt. ssp. tridentata), Wyoming big sagebrush and mountain big sagebrush (A. tridentata Nutt. ssp. vaseyana (Rydb.) Beetle) vary depending on the type of project. Mine reclamations use a larger amount of seed when compared to large-scale rangeland projects. Sagebrush seeding rates for mine reclamation projects range from 1 to $4 \mathrm{~kg} / \mathrm{ha}$ pure live seed (PLS) (Hild, Schuman, Vicklund \& Williams 2006, Schuman \& Belden 2002, Schuman, Booth \& Cockrell 1998, Schuman, Vicklund \& Belden 2005, Vickland, Schuman \& Hild 2004). Large-scale rangeland projects typically use a much lower seeding rates, ranging from 0.05 to $0.56 \mathrm{~kg} / \mathrm{ha}$ PLS (Dalzell 2004, Lambert 2005, Meyer 1992, Monsen 2000, Shaw, Debolt \& Rosentreter 2005). A typical seeding rate when drilling sagebrush ranges from 0.05 to $0.22 \mathrm{~kg} / \mathrm{ha}$ PLS (Lambert 2005, Meyer 1992, Monsen 2000, Shaw, Debolt \&Rosentreter 2005). Broadcast seeding normally requires 33 to 50 percent more seed to be used compared to drilling, with seeding rates ranging from 0.22 to $0.56 \mathrm{~kg} / \mathrm{ha}$ PLS (Dalzell 2004, Meyer 1992, Monsen 2000, Stevens \& Monsen 2004). We recommend a seeding rate of $0.22 \mathrm{~kg} / \mathrm{ha}$ PLS when drilling, and a rate of $0.33 \mathrm{~kg} / \mathrm{ha}$ PLS when broadcast seeding.

The current market price of sagebrush seed may dictate the amount of seed used. Sagebrush seed ranges from $\$ 70$ to $\$ 300 / \mathrm{kg}$ PLS depending on the current market price and availability (Schuman, Vicklund \& Belden 2005). Market prices (2007) for big sagebrush subspecies seed range from $\$ 101$ to $168 / \mathrm{kg}$ PLS (K. Wengreen, personal communication, October 2007). A midrange price of $\$ 135 / \mathrm{kg}$ PLS will be used for economic analysis in this paper.

\subsubsection{Drilling Sagebrush}

The rangeland drill or other single disk drills can be used to plant sagebrush seeds. Drilling commonly requires 33 to 50 percent less seed than broadcast seeding (Stevens \& Monsen 
2004). Big sagebrush may be seeded through drills if seed is dropped on or near the soil surface then covered lightly by press wheels or by pulling a cultivator behind the drill (Lambert 2005, Shaw, Debolt \& Rosentreter 2005). The seed drill should be set to place the sagebrush seed $0.2 \mathrm{~cm}$ into the soil (Lambert 2005), placing seeds deeper than $0.6 \mathrm{~cm}$ reduces emergence (Monsen 2000).

In Nevada, sagebrush was seeded using a traditional rangeland drill to a depth of 0.6 to 1.3 $\mathrm{cm}$ and only 1.2 seedlings $/ \mathrm{m} 2$ established, while leaving the seed on the soil surface resulted in 99 to 101 seedling/m2 (Monsen \& Meyer 1990). In Utah, sagebrush and rabbitbrush were seeded using a Truax rangeland drill and John Deere Flex Drill set to a depth of $1 \mathrm{~cm}$ and 1.4 to 3.9 seedling/m2 established and were present the following year (Cox \& Anderson 2004). Drill seeding sagebrush and rabbitbrush in crested wheatgrass following cultivation resulted in 50 percent more emergence $(2.1$ seedlings $/ \mathrm{m} 2)$ than broadcast seeding only and broadcast seeding followed by covering (Cox \& Anderson 2004).

Many devices have been used to compact the soil surface, resulting in increased sagebrush seedling establishment. These devices are not necessarily drills, but utilize a tractor to go over the soil surface, which is why they have been included in this section. The Oyer compact row seeder compacts the soil then presses the seed into the soil surface (Lysne 2005). In Nevada, use of the Oyer compact row seeder resulted in very high initial sagebrush seedling density (646 seedlings/m2) and 1-year survival (101 seedlings/m2; Monsen \& Meyer 1990). A second implement, the Brillion cultipacker seeder broadcasts the seed over the soil surface then presses it into the soil (Lysne 2005). In Nevada, use of the Brillion cultipacker resulted in emergence of 352 sagebrush seedlings/m2 and 1-year survival of 99 seedling/m2 (Monsen \& Meyer 1990). A Truax Rough Rider drill with brillion wheels was recommended by 3 experts that have experience with establishing sagebrush within crested wheatgrass stands (J. Mangold, personal communication, October 2007; M. Pellant, personal communication, October 2007; N. Shaw, personal communication, October 2007). According to preliminary results, the Truax Rough Rider drill with brillion wheels resulted in sagebrush establishment of 1.3 seedlings $/ \mathrm{m}^{2}$ (N. Shaw, personal communication, October 2007).

The cost of drilling seed is highly dependent on the amount of sagebrush seed used and can range between $\$ 25$ to 40/ha (M. Pellant, personal communication, October 2007). Using a drill at a rate of $\$ 33 / \mathrm{ha}$, and a heavy seeding rate of $0.22 \mathrm{~kg} / \mathrm{ha}$ PLS would be approximately $\$ 63 /$ ha. Drilling sagebrush seed has resulted in sagebrush establishment densities to meet the average found in areas occupied by sage-grouse in central Montana (Woodward 2006).

\subsubsection{Broadcasting Sagebrush}

Conventional tilling and seeding methods may be impractical on some rangelands due to rocky or steep terrain. These sites require land managers to utilize broadcast seeding. Large areas can be seeded with sagebrush quickly using aircraft (Monsen 2000). Aerial broadcasting is often easier than drilling seed, since topography is not a limiting factor (Monsen 2000). Broadcast seeding helps to keep seeds near the soil surface, which is important for planting sagebrush ( Shaw, Debolt \& Rosentreter 2005). 
In Idaho, big sagebrush failed to establish on 23 of 25 fire rehabilitation projects when aerially seeding was used without seedbed preparation (Dalzell 2004). In Utah, broadcast seeding followed by covering the seed resulted in 46 percent more sagebrush and rabbitbrush seedlings than broadcast seeding alone (Cox \& Anderson 2004). Coverage of broadcast seed using chains, harrows, rails, or other implements is recommended to ensure that seed comes into contact with soil surface (Stevens \& Monsen 2004). Light anchor chaining increased seedling density at Dry Creek Drainage, Idaho from approximately 0.6 shrubs $/ \mathrm{m} 2$ on unchained sites to 6.4 shrubs/m2 on chained sites with similar south and west aspects (Monsen 2000). Chaining increased seedling establishment and produced more uniform stands. On a mine reclamation project in Wyoming, sagebrush seed was broadcast seeded using a precision broadcast seeder with cracked corn to accomplish uniform seed distribution and flow through the seeder. Seeding rates between 1 to $4 \mathrm{~kg} / \mathrm{ha}$ PLS were used and had sagebrush establishment densities of 1.0 to 4.5 shrubs/m2 after 6 years (Williams, Schuman, Hild \& Vicklund 2002).

The price of broadcasting sagebrush seed is highly dependent on the amount of sagebrush seed used. The cost of broadcasting depends on the method used. Aerial broadcasting costs $\$ 12$ to $19 /$ ha, while broadcasting on the ground costs $\$ 25$ to 40/ha to apply (M. Pellant, personal communication, October 2007). Using an aerial application at a rate of $\$ 16 /$ ha and a heavy seeding rate of $0.33 \mathrm{~kg} / \mathrm{ha}$ PLS would cost approximately $\$ 61 / \mathrm{ha}$.

\subsubsection{Interseeding and Transplanting Sagebrush}

Interseeders and transplanters are another category of mechanical equipment that may be used to remove competition in narrow bands while planting shrubs in a one-pass operation (Giunta, Christensen \& Monsen 1975, Stevens 1992, Stevens, Moden \& Mckenzie 1981). Two methods for removing vegetation prior to interseeding or transplanting include scalping or herbicide (Stevens 1992). Scalping is done using modified disks or a plow pulled behind a tractor; it must be wide and deep enough to remove or kill all seeds or rhizomes of existing vegetation (Stevens 1992). Existing vegetation can also be killed in strips or spots with herbicide. Sprayed areas can then be seeded by drill or broadcast seeding (Stevens 1992). Scalping or herbicide gives seeded plants a chance to become established before competing vegetation reinvades (Stevens 1992). The width of the scalp or herbicide spray area depends on the density, vigor, and growth form of the major species in the existing vegetation, the species to be interseeded and site conditions (Stevens 1992). Results from interseeding and transplanting are variable depending on local conditions, use of proper techniques, and plant materials used (Stevens 2004).

Interseeding techniques can be used to plant seedlings mechanically in areas that have been scalped or sprayed with herbicide. Scalped areas should be at least $61 \mathrm{~cm}$ wide when planting shrubs (Giunta, Christensen \& Monsen 1975). One study suggested that scalp width should be at least $100 \mathrm{~cm}$ wide, an optimum width of $150 \mathrm{~cm}$ (Van Epps \& McKell 1978).

Sagebrush seedlings (12 to $20 \mathrm{~cm}$ tall) have been planted in early spring using field-grown bare root stock or greenhouse-grown containerized plants (Lambert 2005). Springtime is optimal for transplanting because soil moisture is high, temperatures are low, and chance of 
rainfall is high (Stevens 2004). Transplanting bare root stock may be superior to container-grown stock (Stevens and others 1981). First year survival rates are commonly 80 percent or higher (Lysne 2005), although losses following the first year can range from 46 to 69 percent (Stevens, Moden \& Mckenzie 1981). It is recommended that sagebrush seedlings be randomly placed in clumps or blocks on the best sites within the restoration area. Typically, only small critical areas are planted because of the high cost of using planting stock (Lysne 2005). These sites will become fertile islands of big sagebrush as they mature, and provide a seed source for natural regeneration (Lambert 2005). However, natural regeneration would take many years since sagebrush seeds are very small $(0.018 \mathrm{~g} / 100$ seeds to $0.025 \mathrm{~g} / 100$ seeds depending on variety) and maximum dispersal distances are in the range of $30 \mathrm{~m}$, but 85 to 90 percent fall within $1 \mathrm{~m}$ of the canopy (Young \& Evans 1989).

The cost of bare root stock or greenhouse-grown containerized plants of Wyoming big sagebrush can be greater than $\$ 2 /$ seedling, therefore to achieve the $1 \mathrm{shrub} / \mathrm{m} 2$ density would require a minimum of 2,000 seedlings at a cost of \$4,000/ha (Schuman, Vicklund \& Belsen 2005). Large-scale plantings would not be cost-effective across all rangelands, making this a viable option only for small restoration projects.

\section{Conclusion}

Crested wheatgrass forms large homogenous stands lacking the sagebrush and plant species diversity required by sage-grouse (Crawford et al. 2004, Heidinga \& Wilson 2002). The purpose of this paper was to determine the best methods to suppress crested wheatgrass in order to establish sagebrush to enhance these areas for sage-grouse based on the current scientific literature. Crested wheatgrass cover must be reduced for sagebrush to be seeded and successfully established, thus improving areas for sage-grouse habitat. The presence of sagebrush is the best predictor for sage-grouse use. No technique has proven to eliminate crested wheatgrass in a single application. Repeated treatments or combinations of treatments may be necessary to reduce crested wheatgrass biomass below 14\% cover (Cox \& Anderson 2004) and increase the establishment of seeded species.

Sagebrush establishment is most successful when using a drill with a seeding rate of at least 0.22 kg/ha PLS (Lambert 2005, Monsen \& Meyer 1990, Meyer 1992, Monsen 2000, Shaw, Debolt \& Rosentreter 2005). According to S. Monsen (personal communication 2007), the method of seeding sagebrush is not a crucial factor, however, it is critical that sagebrush seed is not buried too deeply. This means that you can probably drill or broadcast seed sagebrush, although higher establishment rates have been achieved using drills with light soil covering.

Achieving a shrub density of 1 shrub/m2 would be acceptable, however 1.2 to 1.4 shrubs/m2 would provide better habitat for sage-grouse (Woodward 2006). It may not be possible to evaluate seeding success until at least eight years after initial seeding (Schuman, Vicklund \& Belden 2005).

\section{References}

Ambrose, L. G., \& Wilson, S. D. (2003). Emergence of the introduced grass Agropyron cristatum and the native grass Bouteloua gracilis in a mixed-grass prairie restoration. 
Restoration Ecology, 11, 110-115. http://dx.doi.org/10.1046/j.1526-100X.2003.00020.x

Bakker, J. D. (1996). Competition and the establishment of native grasses in crested wheatgrass fields (Thesis). Regina, Saskatchewan: University of Regina. 70 p.

Bakker, J. D., Christian, J., Wilson, S. D., \& Waddington, J. (1997). Seeding blue grama in old crested wheatgrass fields in southwestern Saskatchewan. Journal of Range Management, 50, 156-159. http://dx.doi.org/10.2307/4002373

Bakker, J. D. \& Wilson, S.D. (2004). Using ecological restoration to constrain biological invasion. Journal of Applied Ecology, 41, 1058-1064. http://dx.doi.org/10.1111/j.0021-8901.2004.00962.x

Bakker, J. D., Wilson, S. D., Christian, J. M., Li, X. D., Ambrose, L. G., \& Waddington, J. (2003). Contingency of grassland restoration on year, site, and competition from introduced grasses. Ecological Applications, $\quad 13, \quad 137-153$. http://dx.doi.org/10.1890/1051-0761(2003)013[0137:COGROY]2.0.CO;2

Barnett, J. K., \& Crawford, J. A. (1994). Prelaying nutrition of sage grouse hens in Oregon. Journal of Range Management, 47, 114-118. http://dx.doi.org/10.2307/4002817

Bleak, A. T., Frishknect, N. C., Plummer, A. P., \& Eckert, R. A. (1965). Problems in artificial and natural revegetation of the arid shadscale vegetation zone of Utah and Nevada. Journal of Range Management, 18, 59-68. http://dx.doi.org/10.2307/3895468

Caldwell, M. M., Richards, J. H., Johnson, D. A., Nowak, R. S., \& Dzurec, R. S. (1981). Coping with herbivory: photosynthetic capacity and resource allocation in two semiarid Agropyron bunchgrasses. Oecologia, 50, 14-24. http://dx.doi.org/10.1007/BF00378790

Call, C. A. \& Roundy, B. A. (1991). Perspectives and processes in revegetation of arid and semiarid rangelands. Journal of Range Management, 44, 543-549. http://dx.doi.org/10.2307/4003034

Connelly, J. W., Arthur, W. J., \& Markham, O. D. (1981). Sage grouse leks on recently disturbed sites. Journal of Range Management, 34, 153-154. http://dx.doi.org/10.2307/3898135

Connelly, J. W., Schroeder, M. A., Sands, A. R., \& Braun, C. E. (2000). Guidelines to manage sage grouse populations and their habitats. Wildlife Society Bulletin, 28, 967-985.

Connelly, J. W., Wakkinen, W. L., Apa, A. D., \& Reese, K. P. (1991). Sage grouse use of nest sites in southeastern Idaho. Journal of Wildlife Management, 55, 521-524. http://dx.doi.org/10.2307/3808984

Cook, C. W. (1974). Surface rehabilitation of land disturbances resulting from oil shale development: final report. Fort Collins, CO: Environmental Resources Center. p123.

Cook, C. W., Stoddart, L. A., \& Kinsinger, F. E. (1958). Responses of crested wheatgrass to various clipping treatments. Ecological Monographs, 28, 237-272. http://dx.doi.org/10.2307/1942242 


\section{Mll Macrothink}

Environmental Management and Sustainable Development

ISSN 2164-7682

Cox, R. D. \& Anderson, V. J. (2004). Increasing native diversity of cheatgrass-dominated rangeland through assisted succession. Journal of Range Management, 57, 203-210. http://dx.doi.org/10.2307/4003920

Crawford, J. A., Olson, R. A., West, N. E., Mosley, J. C., Schroeder, M. A., Whitson, T. D., Boyd, C. S. (2004). Ecology and management of sage-grouse and sage-grouse habitat. Journal of Range Management, 57, 2-19. http://dx.doi.org/10.2307/4003949

Dalzell, C. R. (2004). Post-fire establishment of vegetative communities following reseeding on south Idaho's Snake River Plain. (Thesis). Boise, ID: Boise State University. 112 p.

Delong, A. K., Crawford, J. A., \& Delong, D. C. (1995). Relationships between vegetational structure and predation of artificial sage grouse nests. Journal of Wildlife Management, 59, 88-92. http://dx.doi.org/10.2307/3809119

Deluca, T. H. \& Lesica, P. (1996). Long term harmful effects of crested wheatgrass on Great Plains grassland ecosystems. Journal of Soil and Water Conservation, 51, 408-409.

Dillman, A. C. (1946). The beginnings of crested wheatgrass in North America. Journal of the American Society of Agronomy, 38, 237-250. http://dx.doi.org/10.2134/agronj1946.00021962003800030004x

Drut, M. S., Crawford, J. A., \& Gregg, M. A. (1994). Brood habitat use by sage grouse in Oregon. Great Basin Naturalist, 54, 170-176.

Drut, M. S., Pyle, W. H., \& Crawford, J. A. (1994). Diets and food selection of sage grouse chicks in Oregon. Journal of Range Management, 47, 90-93. http://dx.doi.org/10.2307/4002848

Dunn, P. O., \& Braun, C. E. (1986). Summer habitat use by adult female and juvenile sage grouse. Journal of Wildlife Management, 50, 228-235. http://dx.doi.org/10.2307/3801903

Frischknecht, N. C., \& Harris, L. E. (1968). Grazing intensities and systems on crested wheatgrass in central Utah: response of vegetation and cattle. Tech Bulletin 1388., Washington, DC: U.S. Department of Agriculture, Forest Service. 47 p.

Gates, R. J. (1985). Observations on the formation of a sage grouse lek. Wilson Bulletin, 97, 219-221.

Gee, K., \& Biermacher, J. (2007). Prescribed burning: what is the cost? Ag News, Ardmore, OK: The Samuel Roberts Nobel Foundation. p2.

Giunta, B. C., Christensen, D. R., \& Monsen, S. B. (1975). Interseeding shrubs in cheatgrass with a browse seeder-scalper. Journal of Range Management, 28, 398-402. http://dx.doi.org/10.2307/3897504

Gobin, S. M. (1994). Evaluation of grass establishment, development, and survival under sod conditions in the dry subhumid prairies. (Thesis). Winnipeg, Manitoba: University of Manitoba. 171p. 
Grubb, P. J. (1977). Maintenance of species-richness in plant communities - importance of regeneration niche. Biological Reviews of the Cambridge Philosophical Society, 52, 107-145. http://dx.doi.org/10.1111/j.1469-185X.1977.tb01347.x

Hansen, M. J., \& Wilson, S. D. (2006). Is management of an invasive grass Agropyron cristatum contingent on environmental variation? Journal of Applied Ecology, 43, 269-280. http://dx.doi.org/10.1111/j.1365-2664.2006.01145.x

Heidinga, L., \& Wilson, S. D. (2002). The impact of an invading alien grass (Agropyron cristatum) on species turnover in native prairie. Diversity and Distributions, 8, 249-258. http://dx.doi.org/10.1046/j.1472-4642.2002.00154.x

Henderson, D. C., \& Naeth, M. A. (2005). Multi-scale impacts of crested wheatgrass invasion in mixed-grass prairie. Biological Invasions, 7, 639-650. http://dx.doi.org/10.1007/s10530-004-6669-x

Hild, A. L., Schuman, G. E., Vicklund, L. E., \& Williams, M. I. (2006). Canopy growth and density of Wyoming big sagebrush sown with cool-season perennial grasses. Arid Land Research and Management, 20, 183-194. http://dx.doi.org/10.1080/15324980600705586

Holmgren, R. C. (1956). Competition between annuals and young bitterbrush (Purshia tridentata) in Idaho. Ecology, 37, 370-377. http://dx.doi.org/10.2307/1933148

Hubbard, W. A. (1949). Results of studies of crested wheatgrass. Scientific Agriculture, 29, 385-395.

Hull, A. C. (1974). Species for seeding arid rangeland in southern Idaho. Journal of Range Management, 27, 216-218. http://dx.doi.org/10.2307/3897036

Hull, A. C., \& Klomp, G. J. (1966). Longevity of crested wheatgrass in the sagebrush-grass type in southern Idaho. Journal of Range Management, 19, 5-11. http://dx.doi.org/10.2307/3895516

Johnson, J. D. (2004). Restoring native species to crested wheatgrass dominated rangelands [Thesis]. Bozeman, MT: Montana State University-Bozeman. 58 p.

Kiger, R. O., Berg, W. A., Herron, J. T., Phillips, C. M., \& Atkinson, R. G. (1987). Shrub establishment in the mountain shrub zone. In: Munshower, F. F. [ED.], Proc. 4th Biennial Symposium on Surface Mining and Reclamation of the Great Plains. 17-19 March 1987, Billings, MT: Montana State University, Reclamation Research Unit 8704. p. 132-140.

King, M. A., Waller, S. S., Moser, L. E., \& Stubbendieck, J. L. (1989). Seedbed effects on grass establishment on abandoned Nebraska Sandhills cropland. Journal of Range Management, 42, 183-187. http://dx.doi.org/10.2307/3899468

Klebenow, D. A. (1969). Sage grouse nesting and brood habitat in Idaho. Journal of Wildlife Management, 33, 649-662. http://dx.doi.org/10.2307/3799390

Klebenow, D. A., \& Gray, G. M. (1968). Food habits of juvenile sage grouse. Journal of Range Management, 21, 80-83. http://dx.doi.org/10.2307/3896359 
Klott, J. H., \& Lindzey, F. G. (1990). Brood habitats of sympatric sage grouse and Columbian sharp-tailed grouse in Wyoming. Journal of Wildlife Management, 54, 84-88. http://dx.doi.org/10.2307/3808905

Lambert, S. M. (2005). Seeding considerations in restoring big sagebrush habitat. In: Shaw, N.L., Pellant, M. \& Monsen, S. B. [EDS.]. Sage-grouse habitat restoration. RMRS-P-38., Boise, ID: U.S. Department of Agriculture, Forest Service, Rocky Mountain Research Station. p. $75-80$.

Lane, V. R. (2005). Sage-grouse (Centrocercus urophasianus) nest and brood-rearing sagebrush habitat characteristics in Montana and Wyoming [Thesis]. Bozeman, MT: Montana State University. 63 p.

Lauenroth, W.K., Sala, O. E., Coffin, D. P., \& Kirchner, T. B. (1994). The importance of soil water in the recruitment of Bouteloua gracilis in the shortgrass steppe. Ecological Applications, 4, 741-749. http://dx.doi.org/10.2307/1942004

Laycock, W. A. (1981). Crested wheatgrass. Rangelands, 3, 151-153.

Laycock, W. A., \& Conrad, P. W. (1981). Responses of vegetation and cattle to various systems of grazing on seeded and native mountain rangelands in eastern Utah. Journal of Range Management, 34, 52-58. http://dx.doi.org/10.2307/3898454

Lodge, R. W. (1960). Effects of burning, cultivating, and mowing on the yield and consumption of crested wheatgrass. Journal of Range Management, 13, 318-321. http://dx.doi.org/10.2307/3894788

Looman, J., \& Heinrich, D. (1973). Stability of crested wheatgrass pastures under long-term pasture use. Canadian Journal of Plant Science, 53, 501-506. http://dx.doi.org/10.4141/cjps73-097

Lorenz, R. J. (1986). Introduction and early use of crested wheatgrass in the Northern Great Plains. In: Johnson, K. L. (ED.), Crested wheatgrass: its values, problems, and myths, symposium proceeding, Logan, UT: Utah State University. p. 1-348.

Lorenz, R. J., Rogler, G. A. (1962). A comparison of methods of renovating old stands of crested wheatgrass. Journal of Range Management, 15, 215-219. http://dx.doi.org/10.2307/3895253

Lysne, C. R. (2005). Restoring Wyoming big sagebrush. In: Shaw, N.L., Pellant, M. \& Monsen, S. B. [EDS.]. Sage-grouse habitat restoration. RMRS-P-38., Boise, ID: U.S. Department of Agriculture, Forest Service, Rocky Mountain Research Station. p. 90-98

Marlette, G. M., \& Anderson, J. E. (1986). Seed banks and propagule dispersal in crested wheatgrass stands. Journal of Applied Ecology, 23, 161-175. http://dx.doi.org/10.2307/2403089

Martin, N. S. (1970). Sagebrush control related to habitat and sage grouse occurrence. Journal of Wildlife Management, 34, 313-320. http://dx.doi.org/10.2307/3799015 
Mathews, W. L. (1986). Early use of crested wheatgrass seedings in halogeton control. In: Johnson, K. L. [ED.], Proc. Crested Wheatgrass: Its Values, Problems, and Myths. 3-7 October 1986, Logan, UT: Utah State University. p. 27-28.

Mcadoo, J., Longland, W. S., \& Evans, R. A. (1989). Nongame bird community responses to sagebrush invasion of crested wheatgrass seedings. Journal of Wildlife Management, 53, 494-502. http://dx.doi.org/10.2307/3801155

Meyer, S. E. (1992). Germination and establishment ecology of big sagebrush: implications for community restoration. In: Monsen, S. B., Kitchen, S. G. [EDS.]. Ecology and management of annual rangelands. General Technical Report INT-GTR-313., Ogden, UT: U.S. Department of Agriculture, Forest Service, Intermountain Research Station. p. 244-251.

Monsen, S. B. (2000). Establishment of big sagebrush (Artemisia tridentata) in semiarid environments. In: Entwistle, P. G., DeBolt, A. M., Kaltenecker, J. H., Steenhof, K. [EDS.]. Sagebrush steppe ecosystems. 21-23 June 1999, Boise, ID: U.S. Department of the Interior, Bureau of Land Management. 81-88.

Monsen, S. B., \& Meyer, S. E. (1990). Seeding equipment effects on establishment of big sagebrush on mine disturbances. In: Munshower, F. F. [ED.], Proc. 5th Billings Symposium on Disturbed Land Rehabilitation. 25-30 March 1990, Billings, MT: Montana State University Reclamation Research Unit Publication No. 9003. p. 192-199.

Moynahan, B. J. (2004). Landscape-scale factors affecting population dynamics of greater sage-grouse (Centrocercus urophasianus) in north-central Montana, 2001-2004 [Thesis]. Missoula, MT: University of Montana. 133 p.

Nafus, A. M., Svejcar, T. J., \& Davies, K. W. (2016). Disturbance History, Management, and Seeding Year Precipitation Influences Vegetation Characteristics of Crested Wheatgrass Stands. Rangeland Ecology and Management. 69(2016), 248-256. http://dx.doi.org/10.1016/j.rama.2016.03.003.

Olson, B. E., \& Richards, J. H. (1988). Tussock regrowth after grazing: intercalary meristem and axillary bud activity of tillers of Agropyron desertorum. Oikos, 51, 374-382. http://dx.doi.org/10.2307/3565321

Peat, H. C., \& Bowes, G. G. (1995). Direct seeding into crested wheatgrass: final report. Project 90000088. Saskatchewan Agriculture and Food.

Pellant, M., \& Hall, C. (1994). Distribution of two exotic grasses on public lands in the Great

Basin: status in 1992. In: Monsen, S. B., Kitchen, S. G. [EDS.]. Ecology and management of annual rangelands. General Technical Report INT-GTR-313., Ogden, UT: U.S. Department of Agriculture, Forest Service, Intermountain Research Station. p. 300-306.

Pellant, M., \& Lysne, C. R. (2005). Strategies to enhance plant structure and diversity in crested wheatgrass seedings. In: Shaw, N.L., Pellant, M. and Monsen, S. B. [EDS.]. Sage-grouse habitat restoration. RMRS-P-38., Boise, ID: U.S. Department of Agriculture, Forest Service, Rocky Mountain Research Station. p. 81-92. 
Rogler, G. A., \& Lorenz, R. J. (1983). Crested wheatgrass: early history in the United States. Journal of Range Management, 36, 91-93. http://dx.doi.org/10.2307/3897991

Romo, J. T., Grilz, P. L., \& Delanoy, L. (1994). Selective control of crested wheatgrass (Agropyron cristatum L Gaertn and Agropyron desertorum Fisch) in the Northern Great-Plains. Natural Areas Journal, 14, 308-309.

Sala, O. E., Parton, W. J., Joyce, L. A., \& Lauenroth, W. K. (1988). Primary production of the central grassland region of the United States. Ecology, 69, 40-45. http://dx.doi.org/10.2307/1943158

Schroeder, M. A., Aldridge, C. L., Apa, A. D., Bohne, J. R., Braun, C. E., Bunnell, S. D., Stiver, S. J. (2004). Distribution of sage-grouse in North America. The Condor, 106, 363-376. http://dx.doi.org/10.1650/7425

Schuman, G. E., \& Belden, S. E. (2002). Long-term survival of direct seeded Wyoming big sagebrush seedlings on a reclaimed mine site. Arid Land Research and Management, 16, 309-317. http://dx.doi.org/10.1080/15324980290000430

Schuman, G. E., Booth, D. T., \& Cockrell, J. R. (1998). Cultural methods for establishing Wyoming big sagebrush on mined lands. Journal of Range Management, 51, 223-230. http://dx.doi.org/10.2307/4003211

Schuman, G. E., Vicklund, L. E., \& Belden, S. E. (2005). Establishing Artemisia tridentata ssp wyomingensis on mined lands: science and economics. Arid Land Research and Management, 19, 353-362. http://dx.doi.org/10.1080/15324980500299748

Sharp, L. (1986). Crested wheatgrass: its values, problems, and myths. In: Johnson, K. L. [ED.], Crested wheatgrass: its values, problems, and myths, symposium proceeding, Logan, UT: Utah State University. p. 1-34.

Shaw, N. L., Debolt, A. M., \& Rosentreter, R. (2005). Reseeding big sagebrush: techniques and issues. In: Shaw, N.L., Pellant, M. and Monsen, S. B. [EDS.]. Sage-grouse habitat restoration. RMRS-P-38., Boise, ID: U.S. Department of Agriculture, Forest Service, Rocky Mountain Research Station. p. 99-108.

Sika, J L. (2006). Breeding ecology, survival rates, and causes of mortality of hunted and nonhunted greater sage-grouse in central Montana (Thesis). Bozeman, MT: Montana State University. 118p.

Smoliak, S., \& Dormaar, J.F. (1985). Productivity of Russian wildrye and crested wheatgrass and their effect on prairie soils. Journal of Range Management, 38, 403-405. http://dx.doi.org/10.2307/3899708

Stevens, R. (1992). Interseeding and transplanting to enhance species composition. In: Monsen, S. B., Kitchen, S. G. [EDS.]. Ecology and management of annual rangelands. General Technical Report INT-GTR-313., Ogden, UT: U.S. Department of Agriculture, Forest Service, Intermountain Research Station. p. 300-306. 
Stevens, R. (2004). Establishing plants by transplanting and interseeding. In: Monsen, S. B., R. Stevens, R., Shaw, N. L. [EDS.]. Restoring western ranges and wildlands. General Technical Report RMRS-GTR-136-vol-3., Fort Collins, CO: U.S. Department of Agriculture, Forest Service, Rocky Mountain Research Station. 739-744.

Stevens, R., Moden, W. L., \& Mckenzie, D. W. (1981). Interseeding and transplanting shrubs and forbs into grass communities. Rangelands, 3, 55-58.

Stevens, R., \& Monsen, S. B. (2004). Guidelines for restoration and rehabilitation of principal plant communities. In: Monsen, S. B., Stevens, R., Shaw, N. L. [EDS.]. Restoring western ranges and wildlands. General Technical Report RMRS-GTR-136-vol-1., Fort Collins, CO: U.S. Department of Agriculture, Forest Service, Rocky Mountain Research Station. p. 199-294.

Sveum, C. M., Crawford, J. A., \& Edge, W. D. (1998). Use and selection of brood-rearing habitat by sage grouse in south central Washington. Great Basin Naturalist, 58, 344-351.

United States Fish and Wildlife Service. (2005). Endangered and threatened wildlife and plants, 12-month finding for petitions to list the greater sage-grouse as threatened and endangered, proposed rule. Federal Register, 70, 2244-2282.

Van Epps, G. A., \& McKell, C. M. (1978). Major criteria and procedures for selecting and establishing range shrubs as rehabilitators of disturbed lands. In: Hyder, D. N. [ED.], Proc. 1st International Rangeland Congress. 30-31 March 1984, Denver, CO: Society for Range Management. p. 352-354.

Vickland, L. E., Schuman, G. E., \& Hild, A. L. (2004). Influence of sagebrush and grass seeding rates on sagebrush density and plant size In: Hild, A. L., Shaw, N. L., Meyer, S. E., Booth, D. T., McArthur, E. D. [EDS.]. Seed and Soil Dynamics in Shrubland Ecosystems. 12-16 August 2002, Laramie, WY. Proceedings RMRS-P-31. Ogden, UT: U.S. Department of Agriculture, Forest Service, Rocky Mountain Research Station. p. 40-45.

Wallestad, R. O., Peterson, J. G., \& Eng, R. L. (1975). Foods of adult sage grouse in central Montana. Journal of Wildlife Management, 39, 628-630. http://dx.doi.org/10.2307/3800409

Wallestad, R. O., \& Pyrah, D. (1974). Movement and nesting of sage grouse hens in central Montana. Journal of Wildlife Management, 38, 630-633. http://dx.doi.org/10.2307/3800029

Wallestad, R. O. (1971). Summer movements and habitat use by sage grouse broods in central Montana. Journal of Wildlife Management, 35, 129-136. http://dx.doi.org/10.2307/3799881

Wambolt, C. L., Harp, A. J., Welch, B. L., Shaw, N., Connelly, J. W., Reese, K. P., Tanaka, J. A. (2002). Conservation of greater sage-grouse on public lands in the western U.S.: Implications of recovery and management policies. PACWPL Policy Paper SG-02-02., Caldwell, Idaho: Policy Analysis Center for Western Public Lands. 41p.

Weaver, J. E. (1950). Stabilization of midwestern grassland. Ecological Monographs, 20, 251-270. http://dx.doi.org/10.2307/1948583 
Whisenant, S. G. (1999). Repairing damaged wildlands: a process-orientated, landscape-scale approach. New York: Cambridge University Press. 312p. http://dx.doi.org/10.1017/CBO9780511612565

Williams, M. I., Schuman, G. E., Hild, A. L., \& Vicklund, L. E. (2002). Wyoming big sagebrush density: effects of seeding rates and grass competition. Restoration Ecology, 10, 385-391. http://dx.doi.org/10.1046/j.1526-100X.2002.01025.x

Wilson, S. D., \& Gerry, A. K. (1995). Strategies for mixed-grass prairie restoration: Herbicide, tilling, and nitrogen manipulation. Restoration Ecology, 3, 290-298. http://dx.doi.org/10.1111/j.1526-100X.1995.tb00096.x

Wilson, S. D., \& Partel, M. (2003). Extirpation or coexistence? Management of a persistent introduced grass in a prairie restoration. Restoration Ecology, 11, 410-416. http://dx.doi.org/10.1046/j.1526-100X.2003.rec0217.x

Woodward, J. K. (2006). Greater sage-grouse (Centrocercus urophasianus) habitat in central Montana (Thesis). Bozeman, MT: Montana State University. 92 p.

Young, J. A., \& Evans, R. A. (1986). History of crested wheatgrass in the Intermountain area. In: Johnson, K. L. [ED.], Proc. Crested Wheatgrass: Its Values, Problems, and Myths. 3-7 October 1986, Logan, UT: Utah State University. p. 21-26.

Young, J. A., \& Evans, R. A. (1989). Dispersal and germination of big sagebrush (Artemisia tridentata) seeds. Weed Science, 37, 201-206.

\section{Copyright Disclaimer}

Copyright for this article is retained by the author(s), with first publication rights granted to the journal.

This is an open-access article distributed under the terms and conditions of the Creative Commons Attribution license (http://creativecommons.org/licenses/by/3.0/). 